\section{THE INVESTIGATION OF KADIDIA GEOTHERMAL FIELD (INDONESIA) USING GRAVITATIONAL DATA AND POWER SPECTRUM ANALYSIS}

Sismantoa*, Anis Hoerunisaa, Dikdik Risdiantob, Tony Rahadinatab

aPhysics Department, Universitas Gadjah Mada, Indonesia bMineral and Geothermal Resource Center, Geological Agency, Bandung, Indonesia
Article history

Received

17 August 2021

Received in revised form

15 October 2021

Accepted

7 November 2021

Published Online

20 December 2021

*Corresponding author sismanto@ugm.ac.id

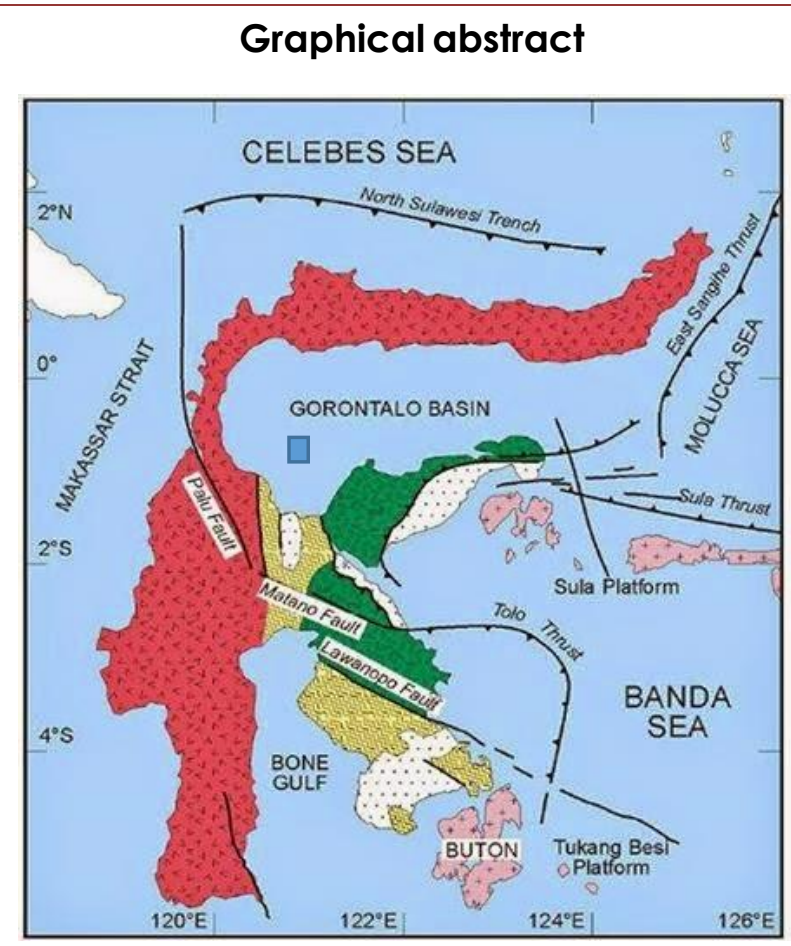

\begin{abstract}
Kadidia is one of the area with geothermal potential in Central Sulawesi, Indonesia. Therefore, this study aims to estimate the depth of reservoir and identify subsurface geological structures using gravity data and power spectrum analysis. It uses secondary data from the field survey results of the geophysical team from the Mineral and Geothermal Resource Center Agency. Furthermore, the data were processed to obtain a complete Bouguer anomaly, reduction in a flat field, regional and residual anomalies. The results of residual anomalies showed high and low values in the range of (5-13) mGal corresponding to volcanic rocks and in the range of 10 to $-4 \mathrm{mGal}$ spread evenly in the study area respectively. The analysis of derivative showed the presence of intrusive rocks which are thought to be granite, and the power spectrum showed that the heat source rocks from the geothermal system were inferred as granite at a depth of more than (3.68-6.00) km. In addition, the reservoir rocks were interpreted as low-density sandstones at a depth of (0.80-1.37) km, and a caprock in the form of sandstones with medium density at a depth of $(0.20-0.80) \mathrm{km}$, and from the surface to $0.20 \mathrm{~km}$ is soil. The interpretation of three-dimensional modeling showed that the faults control geothermal manifestations, i.e. the Koalarawa and Towingkoloe faults, which extends from northwest-southeast.
\end{abstract}

Keywords: Gravity data, Horizontal derivative, and power spectrum analysis, 3D modeling

(C) 2022 Penerbit UTM Press. All rights reserved

\subsection{INTRODUCTION}

Indonesia is a country with considerable geothermal energy potential, which can be identified by the surface manifestations on the surface of the earth. This geothermal manifestation is controlled by faults following the meeting of tectonic plates, and the interactions between rock fluids and hydrothermal mineral deposits, which can be hot springs, hot lakes, hot pools, and fumaroles [1]. Kadidia or K51S field located at Kadidia area, district Nokilalaki, region Sigi, Central Sulawesi Province is one of the geothermal potential areas which has quite complex geological conditions as shown in Figure 1. Furthermore, Sulawesi is 
at the confluence of three major Indonesian tectonic plates, namely the Indo-Australian, Pacific, Eurasian, and Philippine Small plates. The movement of the plates in the region of this province is tangent to one another with quite large faults such as the Palu-Koro, Lawanopo, Poso, and several others. The fault is one of the controllers of geothermal manifestations in the Sulawesi region [2], and those that have surfaced in the Kadidia area are hot scattered in several study points, such as Kadidia, Koalarawa, Nokilalaki, and Towingkoloe hot water, as well as several hot springs.
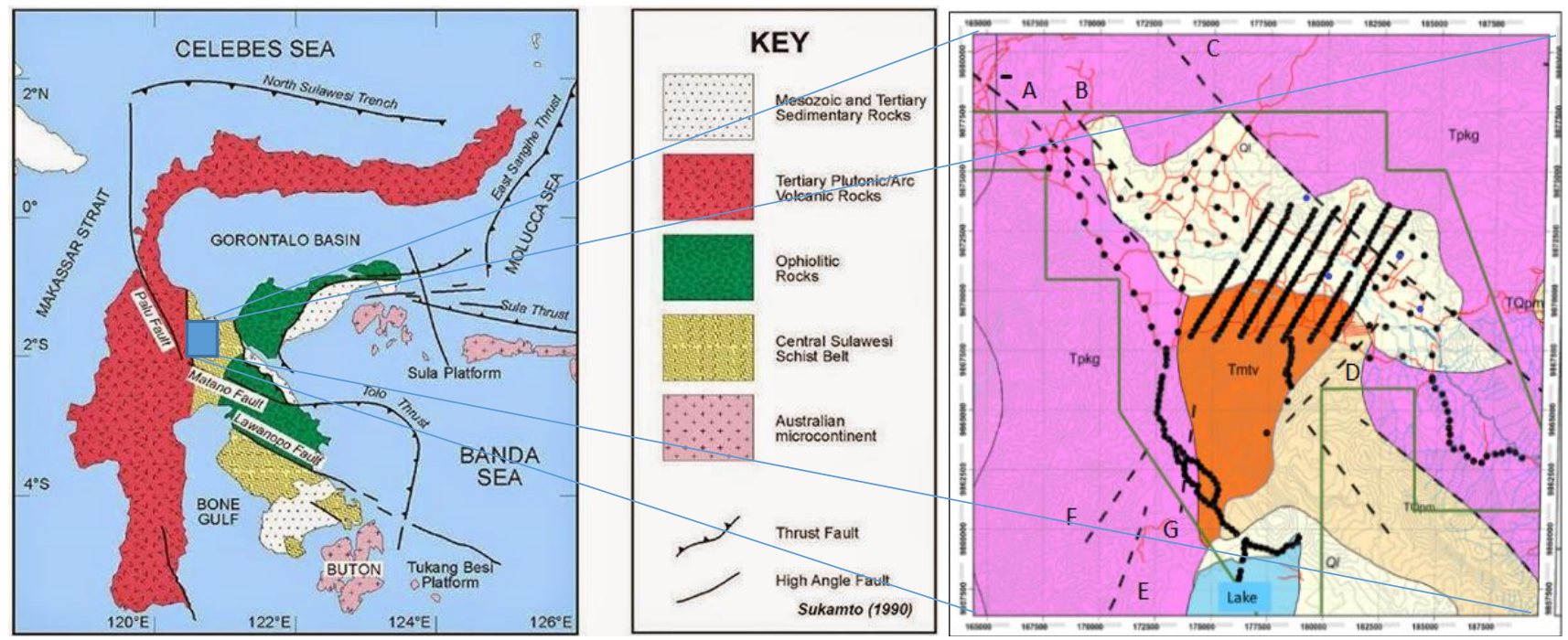

Figure 1 Geological map of the study area, black dots are the gravity points measurements. The name of faults is $A=$ Towingkoloe; $B=$ Koalarawa; $C=$ Kumamora; $D=$ Kaddia; $E=$ Lindu; F and $G$ = Dongi. (Based on the Poso geological map sheet [3])

Gravity method provides sufficient detailed information about the geological structure and density contrasts of subsurface rocks. The difference in the value of the density of subsurface rocks is caused by heat sources accumulated below the surface of the earth. The subsurface density values can cause observational gravitational field on different surfaces [4]. Meanwhile, a horizontal gradient and tilt angle methods can be used to identify geological boundaries in various subsurface structures of Kinigi. Tilt angle methods showed agreements with horizontal gradient by detecting contacts, and provided much better results of boundaries compared with horizontal method [5]. The 3D gravity model of K51S field's the subsurface structure was constructed while the interpretation was not developed [6].

In this study, we estimate the depth of shallow lithology and source based on the 3D gravity model of the subsurface structure by using a power spectrum to clarify the existence and boundaries of gravitational anomalies. As known that the power spectral analysis yields the depths from significant density contrasts in the crust [7].

\section{Geological Setting}

The study area based on geological history is included in the West Sulawesi Mandala, which consists of rocks in the form of Tertiary volcanic products with lava breccias and andesite Towingkoloe mountain products overlain by sedimentation in the form of sandstones and conglomerates. The collision between the Mandala of West and Central Sulawesi triggers the movement of the Sorong Fault to produce a deep rock in the form of a younger granite, and the sediment are then formed in the form of colluvium from Tertiary rocks [8].

The Island of Sulawesi is located between Australia and Sundaland based on tectonic plate analysis [9]. It was formed during the micro-infiltration of the pretertiary continent of Australia located in the southern and western regions such as in the Gorontalo basin. In terms of the evolution of the tectonic model, the island was formed from the reconstruction following the interaction of the Indo-Australian plate collision, the Pacific Plate, and the Eurasian plate [10] which has tectonic abnormalities with a reverse arc model and polarity in the subduction zone.

Several fault segments cause large earthquakes in the Sulawesi region [11], namely the Palu-Koro fault, Saddang fault, and trench where there are several geological structures such as folds and cracks. In the northern part, there are vertical cracks and the western part moves horizontally to the left [12] with an estimated movement speed of 14-17 mm/year [13].

The Palu-Koro Fault has a left-lateral direction of a length of $\pm 300 \mathrm{~km}$ [14] which extends towards the northern subduction zone of the Sulawesi Sea, and some located in water areas. Geological studies for quarter faults [15] and GPS devices [16] showed that there is a shift of $\pm 40 \mathrm{~mm} /$ year across the Palu-Koro Fault zone. However, the shift is not pure since it occurs in the components of the normal substance [15]. The movement of faults can also cause a rock in the 
vicinity to have a very high permeability value, and the energy generated can form an increase in rock heat within the surrounding area. Therefore, when the permeability of the rock is high and followed by high temperatures, it will also result in the accumulation of geothermal energy.

The geological structure of the study area consists of several faults controlling geothermal manifestations. The basement fault is the Koalarawa fault which continues to the northwest, and then cut by a third-period fault trending almost north-south. It forms permeable zones of hydrothermal activity, which can pass hot fluid to the surface [17] as shown in Figure 1.

The study area is composed of rocks that have Tertiary to Quaternary age and are the product of volcanic products, namely Tineba volcanic rock formations, Napu formations, Cambuno granite formations, and lake deposits. The stratigraphy for gravity modeling is shown in Tabel 1.

Table 1 Stratigraphic study area with rock density [18]; [3]

\begin{tabular}{|c|c|c|c|c|c|}
\hline $\begin{array}{l}\text { Lithology } \\
\text { symbol }\end{array}$ & Symbology & $\begin{array}{c}\text { Age of } \\
\text { the rocks }\end{array}$ & Name & composition & $\begin{array}{l}\text { Density } \\
\left(\mathrm{g} / \mathrm{cm}^{3}\right)\end{array}$ \\
\hline 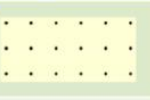 & QI & $\begin{array}{l}\text { Between } \\
\text { Holocene } \\
\text { and } \\
\text { Plistocene }\end{array}$ & Lake sediment & $\begin{array}{l}\text { Clay, silt, sand, dan } \\
\text { gravel }\end{array}$ & $1.20-2.40$ \\
\hline $\begin{array}{llll} & \cdot & \cdot \\
& . & . & . \\
\end{array}$ & Tpkg & $\begin{array}{l}\text { Pliocene to } \\
\text { Plistocene }\end{array}$ & $\begin{array}{l}\text { Kambuno } \\
\text { granite }\end{array}$ & $\begin{array}{l}\text { Granite rock and } \\
\text { grandiorite }\end{array}$ & $2.50-2.81$ \\
\hline 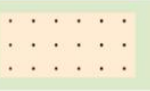 & Tqpm & $\begin{array}{l}\text { Pliocene to } \\
\text { Plistocene }\end{array}$ & Napu formation & $\begin{array}{l}\text { Sandstone, } \\
\text { conglomerate, } \\
\text { siltstone with clay, } \\
\text { peat }\end{array}$ & $1.61-2.76$ \\
\hline 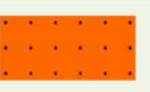 & Tmtv & $\begin{array}{l}\text { Middle to } \\
\text { late } \\
\text { Miocene }\end{array}$ & $\begin{array}{l}\text { Tincba volcanic } \\
\text { rock formations }\end{array}$ & $\begin{array}{l}\text { Andesite lava, } \\
\text { horenblenda, basalt } \\
\text { lava, quartz latite lava } \\
\text { and breccia }\end{array}$ & $2.40-3.30$ \\
\hline
\end{tabular}

\subsection{METHODOLOGY}

The basic principle of the gravity method is Newton's law, which is the force exerted by two objects or particles expressed in the form of unit vectors with masses $m_{0}$ and $m$ separated as far as $\vec{r}-$ $\vec{r}_{0}$ concerning the center of mass. It is directly proportional to the square of the distance and the product of mass between $m_{0}$ and $m$. The magnitude of the force is expressed in [18]:

$$
\vec{F}\left(\vec{r}-\vec{r}_{0}\right)=-G \frac{m \cdot m_{0}}{\left|\vec{r}-\vec{r}_{0}\right|^{2}} \frac{\left(\vec{r}-\vec{r}_{0}\right)}{\left|\vec{r}-\vec{r}_{0}\right|}
$$

where, $\vec{F}(\vec{r})=$ gravitational force $(\mathrm{N}), G=$ universal gravitational constant $\left(6,67 \times 10^{-11} \mathrm{~N} . \mathrm{m}^{2} / \mathrm{kg}^{2}\right), \mathrm{m}=$ mass of objects $m(\mathrm{~kg}), m_{0}=$ mass of objects $m_{0}(\mathrm{~kg}), r$ ^= unit vector direction $m$ to $m_{0}(m),\left|\vec{r}-\vec{r}_{0}\right|=$ distance between object $m$ and $m_{0}$.

Gravitational anomaly $(\Delta \mathrm{g})$ is an effect caused by objects below the surface of the earth. Bouguer anomaly reflects the subsurface anomaly values after the reduction in the gravitational field [18]. It can be determined by using:

$$
\Delta g_{B S}=g_{F A}-g_{B}
$$

where $\Delta g_{B S}$ is a simple anomaly Bouguer gravity field (mGal), $g_{F A}$ is the anomaly value of free air (mGal), and $g_{B}$ is the Bouguer correction gravity field value (mGal). Whereas,

$$
\Delta g_{B L}=g_{B S}+g_{T}
$$

$\Delta g_{B L}$ is a complete Bouguer anomaly (mGal), $g_{B S}$ is the value of a simple Bouguer anomaly (mGal), and $g_{T}$ is the value of the terrain correction (mGal).

This study focuses on shallow and small structures associated with residual anomalies to separate the Bouguer anomaly between regional and residual. Regional anomalies are influenced by deep and large structures, while residuals are caused by shallow and small structures [18], [19]. Anomaly separation was implemented using the upward continuation approach at a height of $2000 \mathrm{~m}$ from the topographical surface. The terrain correction adjusts the Bouguer correction for the effects of variations in thickness of the other horizontal infinite slab. Furthermore, the gravitational attraction of a land mass above the observation station, is away from Earth and decreases the effect of the slab. The upward continuation technique was conducted to smooth the effects of the surface rock.

\section{Three-dimension (3D) Inversion Modeling}

Gravity modeling was conducted with a 3dimensional model to obtain an anomalous distribution of subsurface gravity fields based on a residual anomaly map. In addition, 3D modeling can give a more realistic picture of subsurface conditions close to the actual shape, and it was assisted with Grablox 1.6 and Bloxer 1.6 software [20], [21].

The target area of the study is the Kadidia geothermal field, which is $22.5 \mathrm{~km} \times 25 \mathrm{~km}$ precisely located in Central Sulawesi Province as seen in Figure 1. The secondary data were obtained from the results of field measurements by the Mineral and Geothermal Resource Center Agency (PSDMPB) Bandung in 2012 and 2014. Gravity data from field measurements by PSDMPB are in the form of spatial data, time of measurement, and data with tool height and tidal corrections they were processed by making corrections mGal units, tool height, drift, binding to the tie point at DG0 Bandung (977976.38). Furthermore, several corrections were conducted to reduce some effects that can affect the gravity value in the area of measurement such as free air correction, simple Bouguer correction, and terrain correction to obtain a complete Bouguer anomaly (ABL). $A B L$ values are total anomalies in the measurement area containing local and regional anomalies. The target is a local anomaly used to determine the subsurface structure of geothermal areas. The separation of local and regional anomalies through the upward continuation method upward was conducted by subtracting total from regional anomalies. This local gravity anomaly is then analyzed by conducting 3D modeling to obtain a more tangible subsurface structure. Furthermore, 3D 
modeling is conducted for qualitative and quantitative interpretation of subsurface structures. Inversion modeling was also carried out, and in the first step an initial model was created using Bloxer 1.6 software. It was made by considering several parameters based on the geological review and previous study. The parameters include density, depth, and geological conditions of the study area. In addition, 3D modeling of subsurface structures based on residual or local anomalies was conducted using Grablox 1.6 and Bloxer 1.6 software. The initial model carried out backward modeling through the same software. The steps in inversion are base optimization, density optimization, optimization heights, and Occam d and Occam h. A fairly small error was obtained to describe the level of compatibility between the model and measurement data.

\section{Spectrum Analysis}

Spectrum analysis is used to analyze the phenomenon of harmonic oscillators in nature. It aims to obtain the spectrum distribution of the oscillator phenomenon and to show its statistical characteristics. Furthermore, it is used in the analysis of the 1-dimensional spectrum of the gravitational field anomaly data in one crosssection.

The gravitational field anomaly is a superposition of the regional gravitational field anomaly and the local (residual) gravity field anomaly. Meanwhile, regional gravitational field anomalies that describe the general geological conditions of the study area are characterized by low-frequency, while local anomalies are characterized by high-frequency. The relationship in the frequency area between the gravitational field anomaly and the density distribution along the boundary plane containing the density contrast [22] can be written as follows,

$$
\Delta g(\omega)=2 \pi G \Delta \rho(\omega) e^{-\omega d}
$$

where $\Delta g(\omega)$ is the frequency response of gravity anomaly fields, where $\Delta \rho(\omega)$ is the response frequency of the gravitational field anomaly, $\omega$ is the response frequency of the density contrast, $d$ is the depth of field boundary of the reference spheroid, and is the angular frequency and $G$ is the universal gravitational constant. When the density distribution is random with no relationship with each gravity value, the response frequency can be $\Delta \rho(\omega)=1$, then we get,

$$
E_{n}=C e^{-2 \omega|d|}
$$

where $C$ is a constant, $\omega=2 \pi k$ is the angular frequency, $k$ is the wavenumber (cycle/meter), $d$ is the depth of field boundary $(\mathrm{m})$ below the reference spheroid. Equation (5) can be written:

$$
\log E=\log C-2 \omega|d|
$$

The two logarithmic values which are the difference between the two power spectrums $(E)$ in Equation (6), are obtained,

$$
|d|=-\frac{1}{4 \pi} \frac{\log E_{1}-\log E_{2}}{k_{1}-k_{2}}=\frac{1}{4 \pi} \tan \Phi
$$

where $E_{1}$ and $E_{2}$ are the power spectrum, $k_{1}$ and $k_{2}$ are the wavenumbers, and is the slope angle of the power spectrum curve. Equation (7) shows that the mean depth of the discontinuity plane is proportional to the gradient of the slope of the power spectrum curve.

\subsection{RESULTS AND DISCUSSION}

\section{Complete Bouguer Anomaly}

Gravitational anomaly data from the field measurement results are processed to obtain a complete Bouguer anomaly on topography. The results showed that the gravity field anomaly values in the measurement area are in the range of $(66-114)$ mGal. A high and low anomaly is in the northwest and northeast part of almost north and south of the study area. The complete Bouguer anomaly has value that illustrates the difference in rock density and structure contained below the earth's surface. This complete Bouguer anomaly value is also used as a reference for further processing, i.e., reconstruction to the flat plane and separation of regional and residual anomalies. The contour map is shown in Figure 2.

\section{Regional and Residual Anomalies}

Complete Bouguer anomalies at the point of measurement include regional and residual. Residual anomaly was analyzed and separated from the complete Bouguer anomaly. The anomalous separation method used is an upward continuation, and it is one way of converting gravitational potential field data measured at a surface level into data measured at a higher surface level. The continuation process is conducted using the Oasis Montaj software to calculate coordinate data $(x, y)$ and the complete Bouguer anomaly value. The results obtained from the upward continuation process in the form of regional anomalies obtained residual anomaly. It can decrease the regional anomaly with the value that has been reduced on a flat plane. Lifting at the upward continuation process is conducted at several heights to obtain a smoother regional anomaly map.

\section{Regional Anomaly}

Lifting at the upward continuation stage is carried out at an elevation in stages per $100 \mathrm{~m}$, and the selected altitude is $2000 \mathrm{~m}$. This is because the height shows a fairly stable contour pattern to form a regional anomaly map from upward continuation according to Figure 3, and the values in the study area are in the range of (45 - 63) mGal. In addition, high and low anomalies are in the western and eastern part of the study area. 


\section{Residual Anomaly}

Residual anomalies are obtained following the results of a reduction between regional and complete Bouguer anomalies on a flat plan, and they are obtained in the range of $(-10-13)$ mGal. A high anomaly is seen in the middle precisely in the southwest part of the study area as shown in Figure 4.

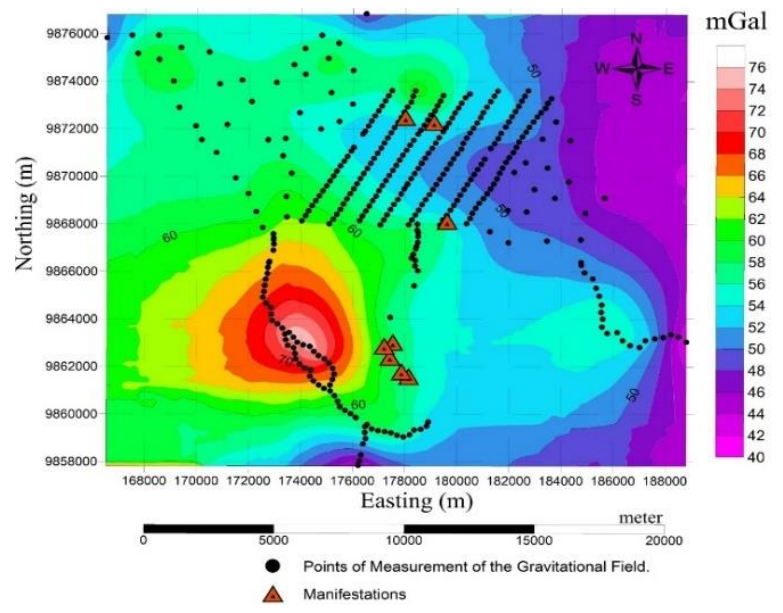

Figure 2 Map of the complete Bouguer anomaly in the study area

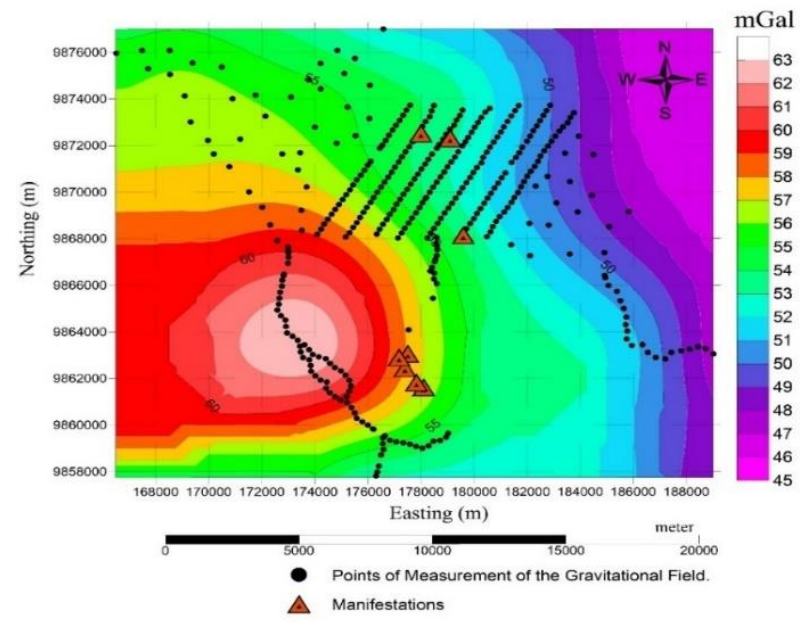

Figure 3 Map of regional anomalies

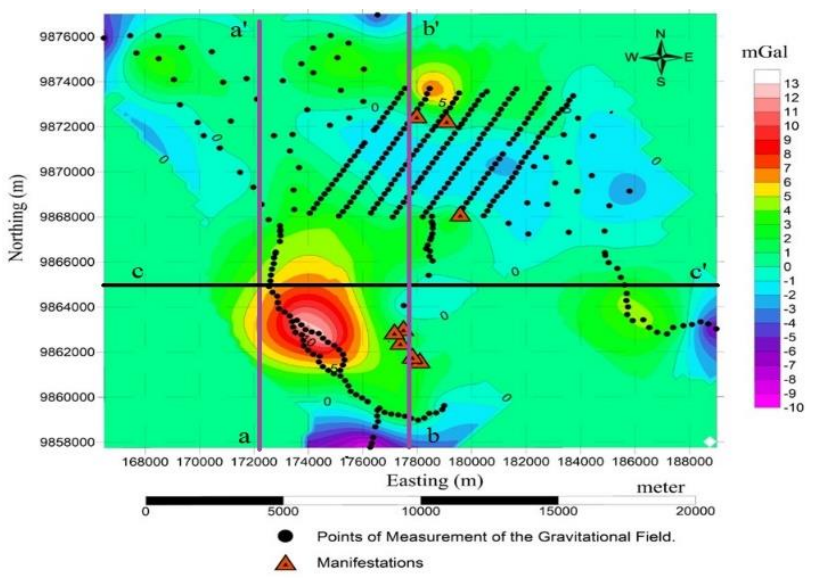

Figure 4 Map of residual anomaly and cross section of a-a', b-b' and c-c' for 3D analysis

\section{Three-dimensional Modeling (3D)}

The inversion of gravity data aims to determine the density distribution and shape of the intrusion of igneous rocks under the Kadidia area. The 3D modeling was conducted using the initial model to obtain a clearer picture of the subsurface structure of the study area [23]. Furthermore, the initial model was created using Bloxer 1.6 software by considering the geological conditions. The inversion modeling was conducted to obtain a Kadidia subsurface model that can clarify the presence of igneous rock intrusion as a source of geothermal energy. Gravity forward and inversion processes were previously conducted using Grablox and Bloxer software for editing and visualizing the block model. The parameters needed to make the initial model are density contrast, geological map of the study area, surface depth following the height of the flat plane reduction, z-axis depth, coordinates of measurement points, number of major and minor blocks, and layers.

The optimization process was conducted on residual and regional gravity data to generate the density distribution influenced by shallow and deep structures. In addition, the initial 3D model by the geological sheet map compiled by Simandjuntak [3] and the study area is composed of alluvial rock, granite, sandstone, and volcanic rock. The study area has a density in the range of $1.20 \mathrm{gr} / \mathrm{cm}^{3}$ to 3.30 $\mathrm{gr} / \mathrm{cm}^{3}$. Alluvial rocks, granite, sandstones and volcanic rocks have an average density of 1.92 $\mathrm{gr} / \mathrm{cm}^{3}, 2.64 \mathrm{gr} / \mathrm{cm}^{3}, 2.35 \mathrm{gr} / \mathrm{cm}^{3}$, and $2.85 \mathrm{gr} / \mathrm{cm}^{3}$. The layers in the 3D model block are adjusted to the lithology and density of the study area. Inverse modeling is conducted on the residual gravity field anomaly data to reduce the influence of rock mass around the study area. Furthermore, 3D modeling aims to determine the distribution of rock mass that affects the value of subsurface gravitational fields [24]. The inversion process in 3D modeling aims to obtain a match between the data obtained following the results of measurements with calculations after considering the smaller value of RMS data and model. The inversion stage is conducted by inversion of anomaly base, density, heights, and Occam inversion and the results of 3D modeling on residual anomaly data are shown in Figure 5.

The results of the 3-dimensional modeling showed the distribution of subsurface density. Based on the lithology of the study area, 3-dimensional modeling is made in 7 layers. This layer has several scattered types of rocks, then analysis at each layer per depth was conducted to obtain sufficient detailed information related to further interpretation. Geological information showed that rocks with a density of (1.20 $2.34) \mathrm{g} / \mathrm{cm}^{3}$ are interpreted as alluvial and low-density sandstones (due to high pressure and faults). Furthermore, densities of $(2.35-2.63) \mathrm{g} / \mathrm{cm}^{3}$ are interpreted as sandstones, while the density (2.64 3.30) $\mathrm{g} / \mathrm{cm}^{3}$ are interpreted as granite and volcanic rock. Analysis of the section model on the $X$ and $Y$ axes was conducted to analyze the distribution of gravity 
anomaly values and rock density of the study area, as well as clarify the interpretation of the overall model. The analysis follows sections a-a', b-b', and c-c' in Figure 4 , and the results showed that there are rocks with a low density of $(1.20-3.30) \mathrm{g} / \mathrm{cm}^{3}$. Rocks with a density of $(1.20-2.34) \mathrm{g} / \mathrm{cm}^{3}$ are interpreted as alluvial, densities of $(2.35-2.63) \mathrm{g} / \mathrm{cm}^{3}$ are interpreted as sandstones, and density $\left(2.64\right.$ - 3.30) $\mathrm{g} / \mathrm{cm}^{3}$ are interpreted as granite and volcanic rock (Figure 6).

High-density anomalous features are found around Koalarawa hot springs, Towingkoloe warm water, and Nokilalaki hot water. This high density is interpreted as granite, and the low-density anomaly is found around Kadidia hot water and Lake Lindu sediment. The results of the qualitative interpretation of $3 D$ modeling showed that the study area contains alluvial rocks which are estimated to be on the surface to a depth of $\pm 0.20 \mathrm{~km}$. Furthermore, the geothermal system in the study area is the presence of suitable cap rocks with sandstones at a depth of $0.80 \mathrm{~km}$. Reservoir rocks in the form of sandstones with lower density are found in the distance of $1.30 \mathrm{~km}$, which is a weak zone of rocks where hot fluids are released, and heat source rocks that correspond to granite at a depth of more than $6 \mathrm{~km}$.

Area with active seismic conditions causes the release of heat energy to the surface, and it can also convex a geothermal model [25]. This occurs in granite rocks that contain phosphorus to store heat, and the process occurs conductively as a heater for meteoric water in the earth's surface.
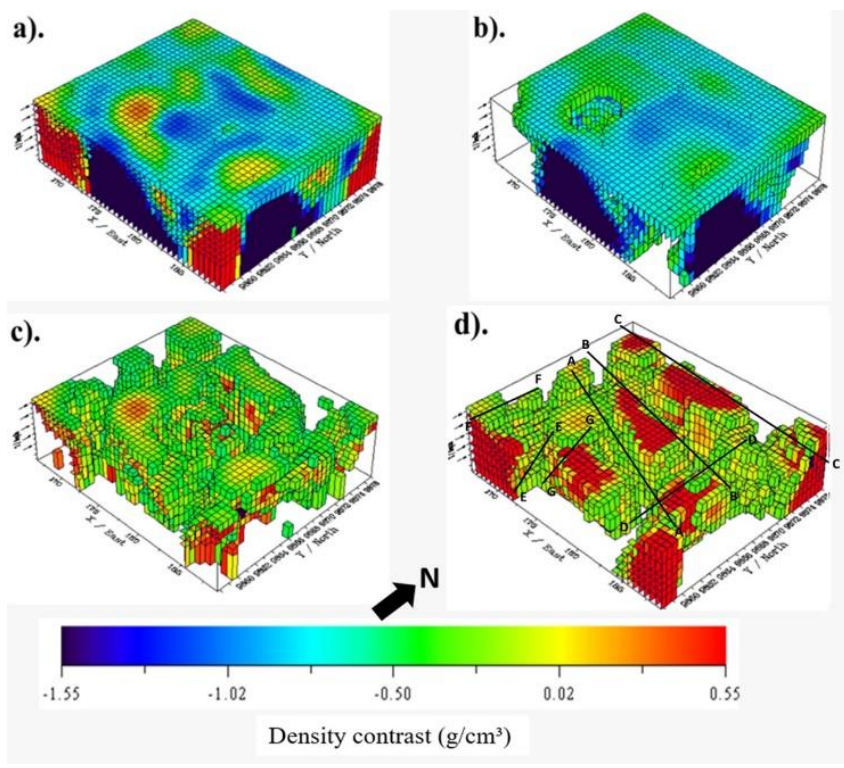

Figure 5 Results of 3D modeling of residual anomaly gravity data a). The subsurface density model results from the inversion, b). Subsurface density models (1.20 - $\left.2.34 \mathrm{gr} / \mathrm{cm}^{3}\right)$, c). Subsurface density models $\left.\left(2.35-2.63 \mathrm{gr} / \mathrm{cm}^{3}\right), \mathrm{d}\right)$. Subsurface density model $\left(2.64-3.30 \mathrm{gr} / \mathrm{cm}^{3}\right)[4]$

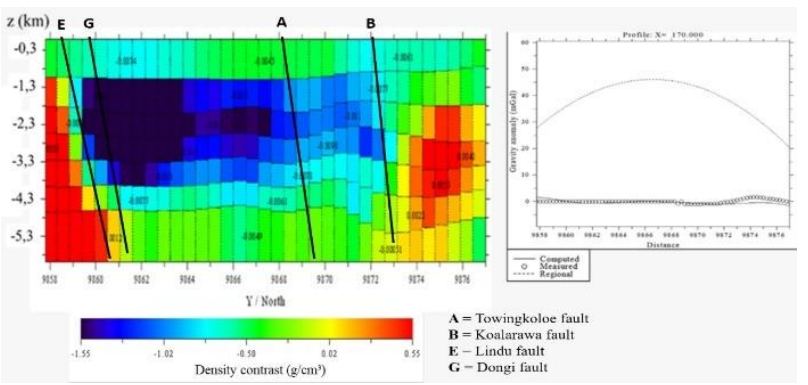

a.

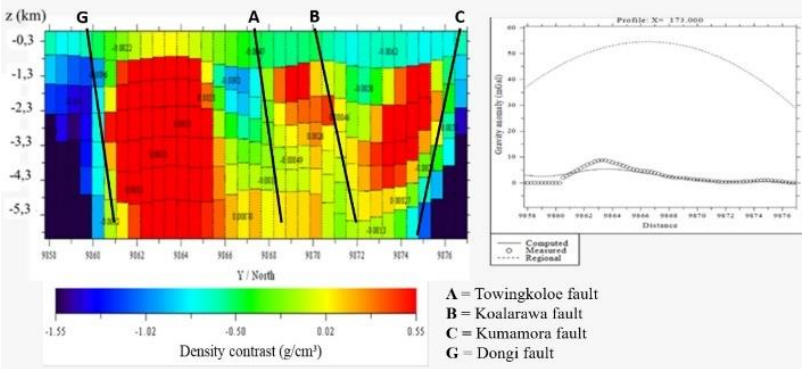

b.

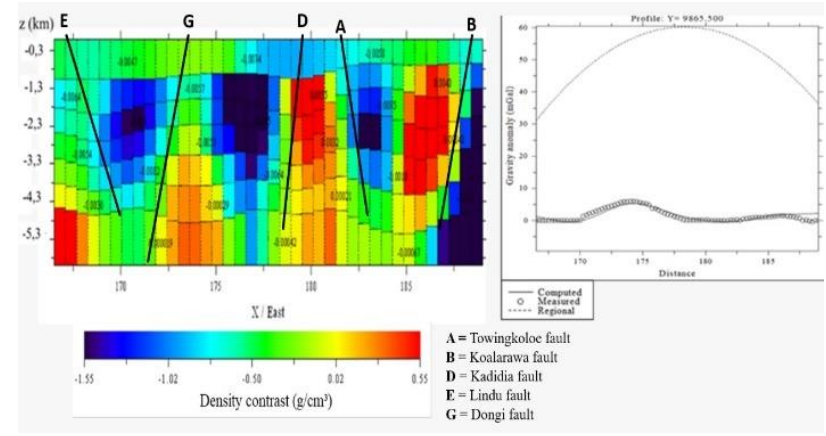

c.

Figure 6 Analysis of a 3D model sections in the study area, a). section $\mathrm{a}-\mathrm{a}$ ' 3D model b). 3D model of section b-b' and c). section $\mathrm{C}^{-c^{\prime}}$ on the 3D model

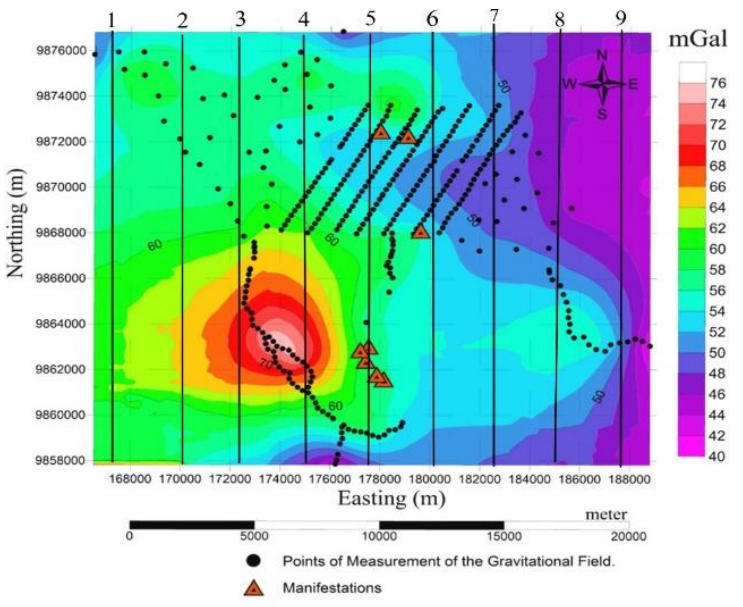

Figure 7 Complete Bouguer anomaly on a $2 \mathrm{~km}$ flat plane and 9-lines for depth analysis estimation 


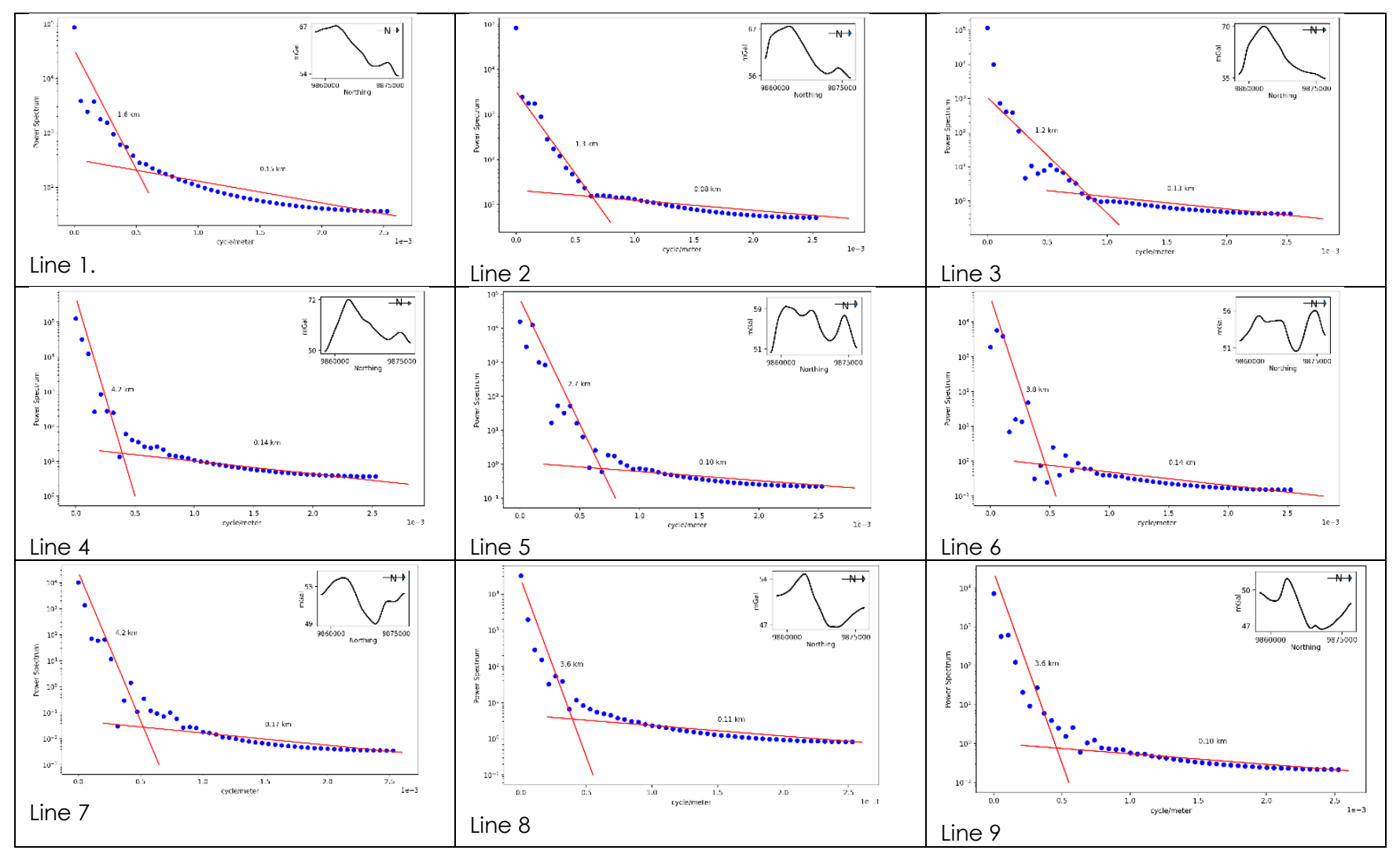

Figure 8 Graph of the power spectrum of each line. The top right curve is a complete Bouguer anomaly section to the position of the lines

Table 2 Estimation of deep and shallow depth of each line from the power spectrum and from 3D modeling

\begin{tabular}{|c|c|c|c|c|c|c|c|c|}
\hline \multirow{2}{*}{$\begin{array}{c}\text { Line } \\
\#\end{array}$} & \multicolumn{3}{|c|}{ Shallow discontinuity estimation } & \multirow{3}{*}{$\begin{array}{l}\dot{\bar{\varepsilon}} \\
\frac{\bar{v}}{N} \\
\stackrel{0}{0} \\
\dot{0}\end{array}$} & \multicolumn{3}{|c|}{ Deep discontinuity estimation } & \multirow{4}{*}{ 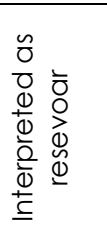 } \\
\hline & $\begin{array}{l}\text { Power } \\
\text { spectrum } \\
(\mathrm{km})\end{array}$ & $\begin{array}{c}\text { Avarage } \\
(\mathrm{km})\end{array}$ & $\begin{array}{c}3 \mathrm{D} \\
\text { modeling } \\
(\mathrm{km})\end{array}$ & & $\begin{array}{l}\text { Power } \\
\text { spectrum } \\
(\mathrm{km})\end{array}$ & $\begin{array}{c}\text { Avarage } \\
(\mathrm{km})\end{array}$ & $\begin{array}{c}3 \mathrm{D} \\
\text { modeling } \\
(\mathrm{km})\end{array}$ & \\
\hline 1 & 0.15 & & & & 1.6 & & & \\
\hline 2 & 0.08 & & & \multirow{8}{*}{ 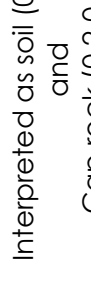 } & 1.3 & 1.37 & $0.80-1.30$ & \\
\hline 3 & 0.13 & & & & 1.2 & & & \\
\hline 4 & 0.04 & & & & 4.2 & & & \multirow{6}{*}{ 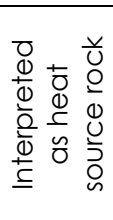 } \\
\hline 5 & 0.10 & 0.11 & 0.20 & & 2.7 & & & \\
\hline 6 & 0.14 & & & & 3.8 & 3.68 & 6.00 & \\
\hline 7 & 0.17 & & & & 4.2 & & & \\
\hline 8 & 0.11 & & & & 3.6 & & & \\
\hline 9 & 0.10 & & & & 3.6 & & & \\
\hline
\end{tabular}

\section{Depth Estimation from the Power Spectrum}

Figure 7 is a complete Bouguer anomaly on a flat plane with an altitude of $2 \mathrm{~km}$ and several line slices for analysis and depth estimation. The eastern part of the study area showed that the complete Bouguer anomaly value is lower in comparison to the western part. In addition, 9 slices were analyzed by the power spectrum method shown in Figure 8, with an estimated depth of deep and shallow discontinuous path.
Table 2 showed that the average shallow discontinuity depth value for the study area is around $0.11 \mathrm{~km}$, and it is relatively consistent with the estimated depth by 3D modeling. These rocks have a density of $11.20-$ 2.34) $\mathrm{g} / \mathrm{cm}^{3}$ that are interpreted as alluvial and lowdensity sandstones (due to high pressure and faults).

The depth value of the discontinuity in the western part of the study area is relatively shallower (average $1.37 \mathrm{~km}$ ) than the eastern part, which is deeper with an average of $3.68 \mathrm{~km}$. Therefore, the thickness of the 
deep discontinuities obtained from the power spectrum method compared to the depth estimated from 3D modeling is relatively the same in the west, but deeper in the east.

According to the depth of 3D modeling rocks with densities of $(2.35-2.63) \mathrm{g} / \mathrm{cm}^{3}$ are interpreted as sandstones, and those found in the geothermal system is a reservoir rock with thickness of $0.80-1.37 \mathrm{~km}$, in the west and up to $3.68 \mathrm{~km}$ in the east. The rock thickness from $0.20 \mathrm{~km}$ to $0.80 \mathrm{~km}$ functions as a rock cap, which is thicker in the eastern part and from the surface to $0.20 \mathrm{~km}$ is soil. Based on 3D modeling, the density $(2.64-3.30) \mathrm{g} / \mathrm{cm}^{3}$ is interpreted as granite and volcanic rock at a depth of more than $6 \mathrm{~km}$, and it is interpreted as a heat source.

\subsection{CONCLUSION}

The high anomalies corresponding to granite and volcanic rock consisting of andesite, basalt, latite, and breccia lava are in the middle of the study area. Meanwhile, the low anomalies are spread between the high. The heat source rocks from the geothermal system are inferred as granite at a depth of more than (3.68-6) km while reservoir rocks are interpreted as lowdensity sandstones at a depth of (0.80-1.37) km, and a caprock has medium density at a depth of (0.20-0.80) $\mathrm{km}$, and from the surface to $0.20 \mathrm{~km}$ is soil. The interpretation of three-dimensional modeling showed that faults control geothermal manifestations, i.e., the Koalarawa and Towingkoloe faults found in northwestsoutheast.

\section{Acknowledgments}

The author is grateful to the reviewer of this paper, and the geophysical field survey team at the Mineral and Geothermal Resource Center Agency (PSDMPB) Bandung for providing access to secondary data.

\section{References}

[1] Hochstein, M., P., dan Browne, P., R., L. 2000, Surface Manifestations of Geothermal Systems with Volcanic Heat Sources, Encyclopedia Volcanoes. Geothermal Institute, The University of Auckland. 835-855.

[2] Sompotan, A. F. 2012. Struktur Geologi Sulawesi. Perpustakaan Sains Kebumian. ITB Bandung. https://www.academia.edu/29803956/Buku Geologi Sulawesi Armstrong Sompotan.

[3] Simandjuntak, T., O. Surono, and Supandjono, J. B. 1997. Peta Geologi Lembar Poso Sulawesi. Edisi ke-2. Pusat Penelitian dan Pengembangan Geologi, Bandung.

[4] Hidayat, N dan Basid, A. 2011. Analisis Anomali Gravitasi Sebagai Acuan dalam Penentuan Struktur Geologi Bawah Permukaan dan potensi Geotermal. Jurnal Neutrino. 4(1). DOI: 10.18860/neu.v0i0.1659.

[5] Uwiduhaye, J., H. Mizunaga, Saibi H. 2018. Geophysical Investigation using Gravity Data in Kinigi Geothermal Field, Northwest Rwanda. Journal of African Earth Sciences. 139 184-192. https://doi.org/10.1016/j.jafrearsci.2017.12.016.
[6] Hoerunisa, A., and Sismanto, S. 2020. Interpretasi Anomali Data Gravitasi Daerah Panas Bumi "K51S" Berdasarkan Pemodelan 3D. Jurnal Fisika Indonesia. 24(3): 136-140. DOI: 10.22146/j_.v24i3.56789.

[7] Saibi H., Nishijima, J., Ehara, S. 2006. Processing and Interpretation of Gravity Data for the Shimabara Peninsula Area, South-western Japan. Memoirs of the Faculty of Engineering, Kyushu University. 66: 2. 129-146. https://www.researchgate.net/publication/31900781_Proc essing_and_Interpretation_of_Gravity_Data_for_the_Shima bara_Peninsula_Area_Southwestern_Japan.

[8] Zarkasyi dan Nurdin. 2014. Survei Magnetotelurik dan TDEM Daerah Panas Bumi Kadidia "K51S", Provinsi Sulawesi Tengah. Pusat Sumber Daya Geologi. Bandung.

[9]. Sukamto, R., 1975. Geological map of Indonesia, Ujung Pandang sheet-scale 1: 1,000,000. Geological Survey of Indonesia.

[10] Katili, J. A. 1989. Review of Past and Present Geotectonic Concepts of Eastern Indonesia. Netherlands Journal of Sea Research. 24(2-3): 103-129. https://doi.org/10.1016/0077-7579(89)90143-9.

[11]. Hamilton, W. B. 1979. Tectonics of the Indonesian Region US Government Printing Office. 1078 https://doi.org/10.3133/pp1078.

[12] Katili, J. A. 1971. A Review of the Geotectonic Theories and Tectonic Maps of Indonesia. Earth-Science Reviews. 7(3): 143-163. https://doi.org/10.1016/0012-8252(71)90006-7.

[13] Jaya, A., Nishikawa, O., dan Jumadil, S. 2019. Distribution and Morphology of the Surface Ruptures of the 2018 Donggala-Palu Earthquake, Central Sulawesi, Indonesia. Earth, Planets and Space. 71 (1): 144 https://doi.org/10.1186/s40623-019-1126-3.

[14] Molnar, P., dan Dayem, K. E. 2010. Major Intracontinental Strike-slip Faults and Contrasts in Lithospheric Strength. Geosphere. 6(4): 444-467. https://doi.org/10.1130/GES00519.1.

[15] Bellier, O., Sébrier, M., Seward, D., Beaudouin, T., Villeneuve, M., dan Putranto, E. 2006. Fission Track and Fault Kinematics Analyses for New Insight into the Late Cenozoic Tectonic Regime Changes in West-Central Sulawesi (Indonesia). Tectonophysics. 413(3-4): 201-220. https://doi.org/10.1016/j.tecto.2005.10.036.

[16] Socquet, A., Simons, W., Vigny, C., McCaffrey, R., Subarya, C., Sarsito, D., Ambrosius, B., dan Spakman, W. 2006. Microblock Rotations and Fault Coupling in SE Asia Triple Junction (Sulawesi, Indonesia) from GPS and Earthquake Slip Vector Data. Journal of Geophysical Research. 111 (B8): B08409. https://doi.org/10.1029/2005JB003963.

[17] Wibowo, A., A., E., dan Risdianto, D. 2014, Survei Terpadu Geologi Daerah Panas Bumi Kabupaten Sigi Provinsi Sulawesi Tengah, Pusat Sumber Daya Geologi, Bandung.

[18] Telford, W. M., Geldart, L. P., and Sheriff, R. E. 1990, Apllied Geophysics. Second Edition. Cambridge University Press, Australia.

[19] Blakely, R., J. 1996. Potential Theory in Gravity and Magnetic Application. Cambridge University Press, Edinburgh. https://doi.org/10.1017/CBO9780511549816.

[20] Pirttijarvi, M. 2014. GRABLOX 1.6 Gravity Interpretation and Modelling Using 3D Block Models. User's Guide to Version 1.6. Oulu, Finland: Department of Physics Sciences, University of Oulu.

[21] Pirttijarvi, M., 2012. BLOXER. Interactive Visualization and Editing Software for 3D Block Models. User's Guide to Version 1.6c. Oulu, Finland: Department of Physics Sciences, University of Oulu.

[22] Untung, M., and Sato, Y. 1978, Gravity and Geological Studies in Jawa, Indonesia. Geological Survey of Indonesia \& Geological Survey of Japan.

[23] Lewerissa R, Sismanto S, Setiawan A, and Pramumijoyo S., 2020b. The Igneous Rock Intrusion Beneath Ambon and Seram Islands, Eastern Indonesia, based on the Integration of Gravity and Magnetic Inversion: Its Implications for 
Geothermal Energy Resources. Turkish J Earth Sci. 29: 596616 (C) TÜBITAK, doi:10.3906/yer-1908-17.

[24] Lewerissa, R., Sismanto, S., Setiawan, Pramumijoyo, S. and, Lapono, L. 2020a. Integration of Gravity and Magnetic Inversion for Geothermal System Evaluation in Suli and Tulehu, Ambon, Eastern Indonesia. Arabian Journal of Geosciences. 13: 726. https://doi.org/10.1007/s12517-020-05735-7.

[25] Moeck, I. S. 2014. Catalog of Geothermal Play Types based on Geologic Controls. Renewable and Sustainable Energy Reviews. 37: 867-882.

https://doi.org/10.1016/j.rser.2014.05.032. 